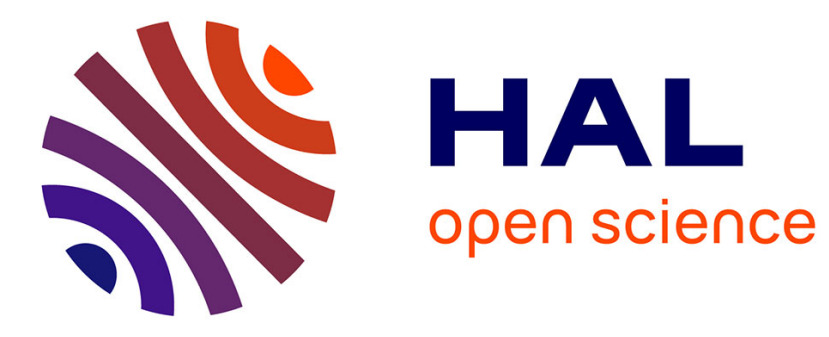

\title{
Endometrium as a biological sensor of embryo quality Olivier Sandra
}

\section{To cite this version:}

Olivier Sandra. Endometrium as a biological sensor of embryo quality. 11. Congress of the European Society for Reproductive Immunology, European Society for Reproductive Immunology (ESRI). HUN., Mar 2014, Budapest, Hungary. 168 p., 10.1016/j.jri.2013.12.025 . hal-02739870

\section{HAL Id: hal-02739870 \\ https: / hal.inrae.fr/hal-02739870}

Submitted on 2 Jun 2020

HAL is a multi-disciplinary open access archive for the deposit and dissemination of scientific research documents, whether they are published or not. The documents may come from teaching and research institutions in France or abroad, or from public or private research centers.
L'archive ouverte pluridisciplinaire HAL, est destinée au dépôt et à la diffusion de documents scientifiques de niveau recherche, publiés ou non, émanant des établissements d'enseignement et de recherche français ou étrangers, des laboratoires publics ou privés. 


\section{S24}

\section{Endometrium as a biological sensor of embryo quality}

Olivier Sandra ${ }^{\mathrm{a}, \mathrm{b}}$

a INRA, UMR1198 Biologie du Développement et Reproduction, Jouy-en-Josas, France

${ }^{\mathrm{b}}$ ENVA, UMR1198 Biologie du Développement et Reproduction, Maisons Alfort, France

In mammals, the birth of viable and healthy progeny involves a continuum of complex biological processes and several checkpoints (or hurdles) that have to be passed successfully. In terms of contribution to pregnancy, the male differs from the female, since the mother not only produces gametes (oocytes), but she also hosts the whole gestation, mainly in the uterus. The uterus is covered with endometrium, a tissue layer endowed with unique features that initiates cellular and molecular interactions with the embryo during implantation, making this step a critical checkpoint of pregnancy. Current data have demonstrated that congenital anomalies, acquired diseases or perturbations of adult maternal physiology before and during reproductive life (e.g. stress, nutrition; endocrine disruptors, infection) can affect endometrial function in a permanent or transient manner. Distinct endometrial responses can also be elicited by embryos presenting distinct post-implantation fates. Indeed biological functions (e.g. metabolism and immune function), molecular pathways (e.g. oxidative phosphorylation) and individual genes (e.g. SOCS3) were affected in bovine endometrium facing various types of embryos produced by artificial insemination, in vitro fertilization or somatic cell nuclear transfer. These findings have led to the concept that endometrium is an early biosensor of embryo developmental potential, which is useful for the prediction of pregnancy issues. This biological property, first demonstrated in cattle, has been recently applied to human species, since the expression of immune genes in decidualized stroma cells was reported to differ in cultured endometrial cells incubated with developing or non-developing embryos. Hence, mammalian endometrium appears as a dynamic and reactive tissue whose physiology can be negatively affected by environmental factors or types of embryos. This compromised or suboptimal endometrial quality can subtly or deeply affect embryo development before implantation, with visible and sometimes severe consequences for the placentation process and fetal development, as well as pregnancy outcome and the long-term health of the offspring.

http://dx.doi.org/10.1016/j.jri.2013.12.025

\section{S25}

G-CSF treatment of patients with recurrent implantation failures (RIF) and recurrent spontaneous abortions (RSA)

\section{Wolfgang Johann Wuerfel}

Kinderwunsch Centrum München - KCM (Fertility Center Munich), Munchen (Munich), Germany

Data from animal experiments showed that colonystimulating factors (CSF) also affect human implantation and embryo development (Robertson \& Seamark, 1992, Moraes \& Hansen, 1997, Tremellen et al., 1998). As early as 2000 , we reported an increase in pregnancy rates among patients with recurrent implantation failures (RIF) patients (Würfel, $300 \mu \mathrm{g}$ molgramostim at embryo transfer); in 2009 Scarpellini and Sbracia reported an increase in birth rates in RSA patients from $48.5 \%$ to $82.8 \%$, while we reported an increase in IVF program pregnancy rates from $27 \%$ to $47 \%$ (Santjohanser et al., 2011, 2013).

Our RIF study was continued after publication, under study conditions also current continued administration to RSA patients after excluding common significant causes of miscarriage $(2 \times 13$ Mio rechG-CSF/week up to the 12 th week of gestation).

RIF patients (more than 6 failed embryo transfers) continue to benefit significantly with pregnancy rates of $43 \%$ for day 5 transfer (control group: $27 \%$ ). RSA patients benefit with an average birth rate of $78.1 \%$ of pregnancies begun.

RIF patients: over 200 children were born, and there was no increase in premature births. In this group follow-up is relatively complete; in the case of a renewed abortion the frequency of genetically abnormal findings was $78.4 \%$. Of all births, one scaphocephaly and one omphalocele were reported, one child was born (outside our Center) in the 36 th week of pregnancy with trisomy 13 . The time of birth was after the 37 th week of pregnancy in $86.3 \%$ (single pregnancies) and between the 32 nd and 37 th week in $11.8 \%$. The average age of the female patients was 36.9 years.

RSA children born: 221 (figure incomplete as not all patient couples return for appointments). Gestational outcome was similar to that of RIF patients.

For a specific group of patients G-CSF is effective at stabilizing pregnancies and increasing birth rates without significant side-effects. Indication is complex: we regard indications as those given in HLA-C haploidentity or weak paternal HLA-C groups (group 2) and in cases where the three activating KIR receptors (2DS1/2DS5/3DS1) are lacking (Faridi et al., 2009; Hiby et al., 2008). At the dosages and length of treatment specified, no danger of malignoma induction is anticipated (Hepp et al., 2009).

http://dx.doi.org/10.1016/j.jri.2013.12.026 